\title{
Kérdések és válaszok egy rangrejtett klasszikusról
}

Fazekas Mihály azon - meglehetősen kisszámú - klasszikus szerzőnk közé tartozik, aki körül látszólag minden rendben van. Létezik müveinek kritikai kiadása (meglehetősen régről, 1955-ből) ${ }^{1}$ van róla nagymonográfia is, Julow Viktor tollából. ${ }^{2}$ Julow a könyvét hosszas kutatások után, évtizedekkel a részben tőle is gondozott kritikai kiadás megjelenése után adta ki: ez a könyv azóta is jelentős teljesítménynek számít. Ezek alapján azt is mondhatnók, nem csoda, hogy az utóbbi időben csönd övezi az író alakját, hiszen minden tisztázva van körülötte.

Pedig korántsem.

Érdemes közelebb lépnünk Fazekas alakjához és teljesítményéhez, mert akkor jobban látszanak a hiányok és a repedések azon a szakirodalmi hagyományon, amely vele foglalkozott.

Nemrég egy új kritikai kiadás indokoltságát vetette fel és fejtette ki részletesen Debreczeni Attila tanulmánya, amely nemcsak az igényt mondta ki, hanem rögtön a lehetséges elvi-módszertani alapozását is megadta egy komoly textológiai vállalkozásnak. ${ }^{3}$ Ez a dolgozat volt a kiindulópontja és ötletadója annak, hogy próbáljunk meg egy egész tanácskozást szentelni a Fazekas Mihály körül felsejlö problémáknak - mert elöször egy tematikus konferenciában gondolkodtunk, amelyre a tőlünk relevánsnak ítélt kérdéskörök szakértőit kértük föl előadónak. A szerzők előzetes felkérését erősen befolyásolták mindazon megfontolások, amelyek az 1955-ös kritikai kiadás használhatósága és maradandósága körül a szervezők számára felvetődtek. A felkért résztvevők vitaindítóként és gondolatébresztőként három tanulmányt is megkaptak elözetesen (ebből kettő Debreczeni Attila munkája volt, időközben mindkettő megjelent, ${ }^{4}$ egy pedig az enyém, amely egy több, mint másfél évtizeddel korábbi tanulmányom ${ }^{5}$ átdolgozott és újragondolt változata), s ezek a szövegek rögtön túl is léptek a textológia határain: Fazekas egész életművének az újraértelmezését szerették volna ösztönözni. A járványhelyzet azonban lehetetlenné tette, hogy valóban találkozzunk. Így módosult az eredeti terv: a

\footnotetext{
${ }^{1}$ FazeKas Mihály Összes Müvei, I-II. kötet, s. a. r. Julow Viktor, KéRY László, Bp., Akadémiai, 1955. (a továbbiakban FMÖM)

${ }^{2}$ Julow Viktor, Fazekas Mihály, Bp., Szépirodalmi, 1982.

${ }^{3}$ Debreczeni Attila, Egy új Fazekas-kiadás alapvetése, ItK, 2019/5, 661-694.

${ }^{4}$ A másik tanulmány: Debreczeni Attila, Kiindulópontok és kontextusok Fazekas Mihály életmüvének újraértelmezéséhez, Alföld, 2019/10, 49-89. Ujjraközlését lásd a jelen tematikus lapszámban: Studia Litteraria, 2020/3-4, 12-55.

${ }^{5}$ SzILÁGyi Márton, Kegyelem és erőszak: Fazekas Mihály Lúdas Matyija, Alföld, 2002/7, 41-57. Átdolgozott változatát lásd a jelen tematikus lapszámban: Studia Litteraria, 2020/3-4, 56-79.
} 
vállalkozás résztvevőit már nem előadásra kértük föl, hanem arra, hogy a vitaindítókra reagálva, saját szempontjaik alapján tanulmányban foglalják össze a véleményüket, s ezeknek a szövegeknek rendeztünk egy zártkörü, interneten lebonyolított megbeszélést, majd az ez alapján újrafogalmazott szövegeket szerkesztettük össze tematikus gyüjteménnyé. A Studia Litteraria szerkesztői pedig voltak olyan kedvesek, hogy ezt az anyagot befogadják folyóiratukba, így mindenki megitélheti, mennyire talált visszhangra az újraértelmező szándék.

A Kéry László és Julow Viktor gondozta kritikai kiadás bevezetése így fogalmazott saját feladatáról és jelentőségéről: „Itt jelenik meg első ízben - a jelen kiadáson alapuló 1955-ös Magyar Klasszikusok-kiadást nem számítva - Fazekas összes fellelhető költeménye, prózai műve, műfordítása és levele; ezek közül több eddig ismeretlen vagy kiadatlan volt. Felvettük kiadásunkba ezenkívül azokat a Fazekasnak tulajdonítható műveket, amelyeknek szerzőségét eldönteni véglegesen még nem lehet. Függelékben hozzuk a Fazekas életére és munkásságára vonatkozó - eddig javarészben ismeretlen vagy kiadatlan - fontosabb dokumentumokat."6 Mindez valóban meg is valósult. Elmondhatjuk: a kritikai kiadás jelentős tudományos teljesítmény, $s$ amit itt felsorol, teljesíti is. ${ }^{7}$

Ám az mégiscsak feltűnhet, hogy Fazekas életművének van egy olyan, nem elhanyagolható méretü és jelentőségü darabja, amelyről ez a pár sor nem beszél. Ez pedig a Magyar Füvészkönyv. ${ }^{8}$ A mellözésére a kritikai kiadás jegyzete később ad is magyarázatot. Ám aligha teljesen meggyőzőt. Így aztán a kritikai kiadásnak ez a hiánya - megítélésem szerint - tünetértékủ. Az a magyarázat ugyanis, amely megokolja a kihagyását, még csak logikusnak sem tünik: „Nem öleli fel kiadásunk a Magyar Füvészkönyvet, mivel nem egyedül F. munkája, s mert a kutatók részére ma is könnyen hozzáférhetö."9 $\mathrm{A}$ társszerzőség önmagában ugyanis aligha indokolná a mellőzését, különösen egy olyan életmű esetében, amelynek jelentős részében éppen a szerzőség kétségtelen megállapítása a legfőbb tét; $s$ ha a munka egyébként könnyü hozzáférhetősége ${ }^{10}$ valóban elegendő érv lenne egy munka kirekesztésére a kritikai kiadásból, akkor számos szövegnek nem lenne helye ott (gondoljunk csak a Lúdas Matyira...) - bár még akkor is jelentős különbség van aközött, hogy egy olvasó az eredeti kiadást veheti-e a kezébe, vagy egy jegyzetelt, az időközben megszületett szakirodalmat is magába építő, tudományos feldolgozásnak tekinthető munkát. Úgy vélem, hogy a Füvészkönyv kihagyása inkább szemléleti és koncepcionális kérdés volt: azt az irodalomtörténeti látásmódot mutatja, amelynek

\footnotetext{
${ }^{6}$ FMÖM I. 181.

7 Egykorú kritikai visszhangja: FenYő István, ItK, 1956/2, 237-241; OLtváNYI Ambrus, Könyvtáros, 1956/1, 64; Kiss József, It, 1957/1, 89-93; V. Windisch Éva, Századok, 1957/5-6, 874.

${ }^{8} \mathrm{~A}$ hiányát persze már az egykorú kritikai is észlelte. Fenyő István szóvá tette kihagyását, kárhoztatólag: FenYő, i. m., 239. Kiss József viszont elfogadta a sajtó alá rendezők döntését: KIss, i. m., 89.

${ }^{9}$ FMÖM I. 194.

${ }^{10}$ Hogy a kritikai kiadás megjelenésekor tényleg könnyen hozzáférhető volt-e a kötet, legalábbis megkérdőjelezhető, ma már azonban valóban megtalálható digitalizált változata az interneten, több példányban is.
} 
a jegyében hagyományosan kezelték Fazekas teljesítményét, noha onnan nézvést bizonyos területek egyszerüen nem is voltak beláthatóak. S hogy ez mennyire általános nézet volt, azt a kritikai kiadásról szóló egyik kritika, a Fenyő Istváné mutatja - ő még a csillagászattal kapcsolatos cikkek közlését is túlzásnak nevezte: „Még egy ilyen szövegkritikai kiadásban is feleslegesnek érezzük a csillagászati cikkek egy részét (Vénus planétáról, Merkurius planétáról, A Holdról, A Saturnusról), irodalmi értékük ezeknek alig van, legfeljebb tudománytörténeti, illetve tudománynépszerüsítéstörténeti [sic! Sz. M.] az érdekesség. Feleslegesnek tartunk néhányat a publikált életrajzi dokumentumok közül is, (mint pl. Fazekas építési engedélyt kér, istállóépítési engedélyt kér, a gyapottermesztés tanulmányozása, derecskei kiküldetése címüeket), mivel ezeknek elvi jelentőségük nincs, filológiai támpontokat pedig nem adnak."11 Most ne bonyolódjunk bele abba, hogy egy kritikai kiadásban közölt szövegnek miért is kellene „elvi jelentőségü"-nek lennie, s hogy vajon mit is jelent az „,irodalmi érték”, amelyet követni kellene - mint ha nem lenne elég feladat egy életmü teljességének a megragadása a kritikai kiadás számára...

Ma már egyre több ilyen, annak idején a szemhatáron kívül maradó, de azóta egyre fontosabbnak tünő terület látszik. Jelen tematikus szám legalább néhány ilyennek a felmérését szeretné kezdeményezni.

Persze az 1950-es évek kritikai kiadásainak elméleti alapozása meglehetősen eltérő $s$ kevéssé összehangolt volt. A legutóbb ezt a kérdést Török Zsuzsa exponálta a szintén ekkor indult Arany-kritikai kapcsán, ${ }^{12} \mathrm{~s}$ tanulmányának köszönhetően, amely aztán belekerült a tőle sajtó alá rendezett kritikai kiadás apparátusába is, ${ }^{13}$ jól látszanak az eltérő megoldások: a Voinovich Gézától koncipiált Arany, ${ }^{14}$ a Keresztury Dezsőtől és Tarnai Andortól gondozott Batsányi ${ }^{15}$ mellett harmadikként a Fazekas-kritikait is érdemes számba venni (ezt Török Zsuzsa nem említi), s így markánsabban feltünnek az eltérö, utólagos nézetből már problematikusnak látszó megoldások.

Fazekas Mihály esetében az első, rögtön feltűnő hiány persze az, hogy ez a két kötet - teljességet ígérő címe ellenére - nem tartalmazza a kiválasztott szerző teljes életművét, s egy olyan, persze inkább más szaktudomány (a botanika) keretébe illeszkedő művet

\footnotetext{
${ }^{11}$ FENYÖ, i. m., 239.

${ }^{12}$ Töвӧк Zsuzsa, Voinovich Géza védelmében? Textológiatörténet és az újrakiadás módszertana, ItK, 2017/4, 499-510.

${ }^{13}$ Arany János, Elbeszélő költemények, s. a. r. Töвöк Zsuzsa, Bp., Universitas - MTA Bölcsészettudományi Kutatóközpont Irodalomtudományi Intézet, 2019 (Arany János Munkái), 768-778.

${ }^{14}$ Voinovich a kritikai kiadás első hat kötetét rendezte sajtó alá: Arany János Összes Müvei, I-VI. kötet, s. a. r. Voinovich Géza, Bp., Akadémiai, 1951-1952.

${ }^{15}$ Batsányi János Összes Müvei, I, Versek, s. a. r. Keresztury Dezső, Tarnai Andor, Bp., Akadémiai, 1953; Batsányi János Összes Müvei, II, Prózai müvek: Első kötet, s. a. r. Keresztury Dezső, Tarnai Andor, Bp., Akadémiai, 1960; BAtsányi János Összes Müvei, III, Prózai müvek: Második kötet, s. a. r. Keresztury Dezső, Tarnai Andor, Bp., Akadémiai, 1961; Batsányi János Összes Müvei, IV., Der Kampf (A viaskodás), s. a. r. Zsındely Endre, Bp., Akadémiai, 1967. Láthatólag a Batsányi-kritikainak csak az első kötete tartozik bele az 50-es évek textológiai munkáinak a sorába.
} 
hagy el, amelyet Fazekas és a kortársai egyaránt fontosnak gondoltak. Fazekas ezt a művét saját neve alatt, s az identitása egyik legfőbb elemének tekinthető katonai rangja („főhadnagy”) feltüntetésével adta ki (míg egyéb műveit jórészt névtelenül hagyta). Az író halála után a róla írott nekrológok pedig éppen ezt a müvét említették legfőbb érdemeként. Mindkét névtelenül megjelent szöveg, amely persze származhat ugyanattól a személytől is, csak ennek a könyvnek a szerzőjeként méltatta Fazekast. ${ }^{16}$ Persze ez utóbbi jelenség nyilván nem független attól, hogy itt Fazekas teljes neve rajta volt a könyvön - bár mivel az ismeretlen szerzők (lehetséges, hogy egy szerző áll mindkét nekrológ mögött) debreceni levelezőknek tekinthetők, föltételezhető, hogy ők ismerhettek más műveket is Fazekastól, illetve tisztában lehettek tevékenységi körének egyéb tényezőivel is, vagyis a Magyar Füvészkönyv kiemelését a nekrológokban akár valamiféle mérlegelés következményének is tekinthetjük. Ha tehát a korabeli nyilvánosságszerkezetből és tudományfelfogásból indulunk ki, nyilván nem mellőzhető az egykorúan főműként kezelt könyv kihagyása; illetve ha ezt praktikus okokból, mondjuk, a szakmai illetéktelenség okán mégis megteszik az irodalomtörténész sajtó alá rendezők, akkor célszerübb lett volna kevésbé nagyralátó kötetcímet választani. Mert ez a két kötet így nem Fazekas „összes művei”-t tartalmazza, az biztos.

A Fazekas-kritikai tehát annyiban feltétlenül beleillik az Arany és Batsányi műveit közlő, említett vállalkozások mellé, hogy nem teljes (az Arany-kritikai csak 2015ben fejeződött be, de még ekkor sem lett komplett, ezért kezdődött el azonnal újra a sorozat, más koncepció szerint, s részben új, még eddig meg nem jelent művekkel; a Batsányi-kritikai végső kiegészítése pedig jelenleg is zajlik a levelezéskötetek sajtó alá rendezésével). A paradoxon azonban éppen az a dologban, hogy a Fazekas-kritikai ennek ellenére befejezett munka: hiszen két kötetre tervezték, $s$ mindkettő meg is jelent 1955-ben. Persze ez a kétségtelen sikeresség nyilván összefügg azzal, hogy ez a legkisebb terjedelmü életmű a háromból. Tegyük hozzá, azóta sem nagyon bukkant fel olyan egyéb szöveg, amely gazdagította volna Fazekas Mihály életművét. ${ }^{17}$ Ha tehát most egy új kritikai kiadás szükségessége merül föl, ez nem azért történik, mert ezt számos új mủ előkerülése kényszerítette volna ki. Annak idején Kiss József igen részletes recenziójában egyetlen ponton adott hangot a bizonytalanságának: „A kiadásban közzétett anyag teljessége tekintetében csupán egyetlen kételyem merült fel. Ez összefügg azzal a több tekintetben zavaró körülménnyel, hogy a szerkesztők a Magyar Tudományos Akadémia első, 1952-ben kiadott szabályzata alapján kezdték meg munkájukat (Ma-

\footnotetext{
${ }^{16}$ A Fazekasról szóló, két egykorú nekrológ: Magyar Kurir, 1828. márc. 4., 142.; Hazai ’s Külföldi Tudósítások, 1828. márc. 8., 153-154.

${ }^{17}$ Legfeljebb néhány kisebb jelentőségű müről lehet beszámolni: a Mundus vult decipi, decipiatur ergo címü, bizonytalan szerzőségü, valamint a kétes hitelü Csokonai Vitéz Mihályhoz címü versre lehet gondolni, nem beszélve két botanikai jegyzetröl. Az első verset először kiadta: SzILÁGYi Ferenc, Fazekas Mihály ismeretlen verse, ItK, 1972/1, 74-79. Hitelességének a mérlegelését lásd DeBreCzENI, Egy új Fazekas-kiadás alapvetése, i. m., 681. A második vers 1805. márc. 29-én jelent meg a Magyar Kurírban, hitelességének a mérlegelését lásd uo., 665.
} 
gyar klasszikusok kritikai kiadásának szabályzata. Magy. Tud. Akad. Nyelv- és írod. tud. Oszt. Közl. 1952. 3. köt. 1-2. sz. 53-55. 1.), mely a levelekre nézve így rendelkezik: »A klasszikusok műveinek teljes kiadása tartalmazza az író ... leveleit is. A levelek elözményeire és a válaszlevelekre a jegyzetekben kell utalni«. Az első kiadási szabályzat tehát - ellentétben a másodikkal (lásd uo. 1954. 5. köt. 239. 1.) - még nem írja elő az íróhoz intézett levelek összegyüjtését és közlését. Julowék a jegyzetekben az egyes levelekre küldött válaszokat - nagyon helyesen - egész terjedelmükben közlik, de mivel e kérdésről sehol nem írnak, nem tudjuk, vajon egyéb, a költőhöz írt, de más levelek jegyzetébe nem illeszthető leveleket az első szabályzatnak megfelelően nem mellőztek-e. Mindjárt hozzáteszem azonban, hogy ha volnának ilyenek, valószínüleg legalábbis a Függelékbe felvették volna öket. Magam is nyomoztam Fazekashoz írt levelek után, de budapesti kézirattárakban és különféle nyomtatott forrásokban végzett kutatómunkám semmi eredménnyel sem járt." ${ }^{18}$ Kiss József láthatólag maga cáfolta meg a saját maga felvetette gyanút, s a kritikai kiadás megjelenése óta eltelt évtizedek őt igazolták: azóta sem kerültek elő kallódó Fazekas-levelek.

Sajnos.

A Debreczeni Attila kezdeményezte Fazekas-revízió, amely egyaránt kiterjed textológiai és interpretációs kérdésekre, sokkal inkább azoknak a szempontoknak a felmutatását és figyelembe vételét jelenti, amelyek az utóbbi években egyre inkább fontosnak bizonyultak, s amelyek annak idején nem kaptak helyet a régi Fazekas-kritikai koncipiálásakor.

Fazekas számos szempontból saját kora irodalmi nyilvánosságának egyedi és különös alakja volt. Fennmaradt leveleinek csekély száma is jól mutatja azt, hogy nem nagyon tartozott bele korának irodalmi hálózataiba (ezzel még akkor is számolni kell, ha a levelek fennmaradásának véletlene, s Fazekas hagyatékának szétszóródása is magyarázhatja természetesen a feltűnően kevés misszilist). Ilyenformán az irányzatosság vagy a csoportképződés logikája sem segíti irodalomtörténeti elhelyezését (ebben nagyon hasonlatos a helyzete például Katona Józseféhez). Nagyon kevés dokumentum áll rendelkezésre az életpályájáról, így biográfája újraírása sem igen lehetséges (mondhatnók, hasonló a helyzet Berzsenyi Dániel esetében is). Feltűnő, hogy kortársai mennyire kevéssé tartották őt fontosnak, s ennek jelzéseként mennyire nem készültek róla viszszaemlékezések vagy alakját felidézni kívánó, akárcsak kultikus töltetű szövegek; ez különösen ahhoz mérten érdekes, hogy a baráti köréhez tartozó Csokonai Vitéz Mihályról viszont éppúgy rendelkezésre áll önálló könyvként megjelent emlékezés (Domby Márton munkája) ${ }^{19}$ mint ahogy Csokonai édesanyja ösztönzésére elindult a róla szóló emlékek begyüjtése is ${ }^{20} \mathrm{~s}$ részben ez tette lehetővé a nem lebecsülendő terjedelmü,

\footnotetext{
${ }^{18}$ KIss, i. m., 89-90. Mellesleg Kiss recenziója volt a kritikai visszhang legtartalmasabb darabja.

${ }^{19}$ Domby Márton, Csokonay V. Mihály élete 's Némely még eddig ki nem adott munkái, Pesten, Trattner János Tamás' betüivel, 1817.

${ }^{20}$ Vö. Szilágyi Márton, A költő mint társadalmi jelenség: Csokonai Vitéz Mihály pályafutásának mikrotörténeti dimenziói, Bp., Ráció, 2014, 375-386.
} 
Csokonai-emlékek című kötet létrejöttét is Vargha Balázs jóvoltából. ${ }^{21}$ Fazekas esetében egy ilyen jellegü kötetnek az előfeltételei is hiányoznak (magyarán: nincs annyi forrás, amivel meg lehetne tölteni egy ilyen könyvet), ami arra utal, hogy ugyanaz a környezet máshogyan viszonyult Fazekashoz, mint Csokonaihoz. Aligha tudunk a Julow Viktor monográfiájában szereplő adatokhoz képest új forrásokkal előállni róla (legalábbis ilyenek az elmúlt harminc, negyven évben nem kerültek elö). Életművének a korpusza is alapvetően változatlan: azokkal a művekkel kell számolnunk, amelyeket már a kritikai kiadás is közölt, s amelyeket Julow Viktor elemzett vagy kommentált a könyvében. Mindazonáltal Fazekas Mihály személyében saját korának egészen sajátos pozícióban lévő alkotójáról van szó. S ezeknek a kontextusoknak a fölvázolásával egészen más fénytörésben láthatjuk ezt az alkotói pályát.

Fazekas kapcsán megértendő és elemzendő lenne az irodalmi szocializációnak egy olyan közege, amelyről meglehetősen keveset tudunk: ez pedig a katonaság világa. Tudjuk, hogy Fazekas közkatonaként állt be a Barco-huszárezredbe, ${ }^{22} \mathrm{~s}$ folyamatos szolgálata következtében - nyilván a napóleoni háborúk gyors előléptetéseket is lehetővé tevő közege révén - elérte a föhadnagyi rangot. Ez a periódus tette lehetővé első, az ő neve alatt megjelenő versei születését. A [Feltette hatalmas... ] kezdetü verset 1789. dec. 29én közölte a Hadi és Más Nevezetes Történetek, egy külön jegyzetben adva meg a mü szerzőjének nevét is: „Ezen kellemetes verseknek szerzője Fazekas Mihály úr, Császár húszárreg.-béli hadnagy. - Irta még szept.-ben, az ispotályban létében. - Közlötte velünk a gerlecsenii táborból Dobozy Lajos ur, a fenn nevezett urnak tiszti társa." ${ }^{23}$ Fazekasnak ezekről az éveiről is igen keveset tudunk, s még csak a hadtörténeti részleteket sem szedte össze senki, de ez a néhány sor még így is tartalmaz néhány igen figyelemreméltó adatot. A versírás lehetséges alkalmát ezek szerint a sebesülésből történő lábadozás adta, mint ahogy témáját a katonai szolgálat - $\mathrm{s}$ mivel a verset nem maga a szerző, hanem egy másik tiszt juttatta el a folyóirathoz, ennek a tevékenységnek láthatólag volt helyben közönsége. Ráadásul legalább egy olyan személy (neki még a nevét is tudjuk), aki az elérhető publikációs fórumok létével is tisztában volt. Ennek a közegnek a vizsgálata tehát akár általánosítható tanulságokat is ígérne, hiszen a korszak más írói indulásainak a kezdete is a tisztikar világában keresendő. Gondoljunk csak Gvadányi Józsefre ${ }^{24}$ vagy akár a testőrségből kilépett, $s$ katonatisztként szolgáló Kisfaludy Sándorra, aki a Himfy szerelmei előszavában külön utalt is a kötet első felének a születése kapcsán a hadifogság körülményeire.

\footnotetext{
${ }^{21}$ Csokonai emlékek, kiad. VArgha Balázs, Bp., Akadémiai, 1960.

${ }^{22}$ Erről lásd NAGY István, Melyik lovasezredben szolgált a Ludas Matyi szerzője, Debreceni Szemle, 1936/1, 26-31.

${ }^{23}$ FMÖM I. 207. (kiemelések az eredetiben)

${ }^{24}$ Ennek a legérdekesebb költői dokumentuma, egy annak idején publikált alkalmi vers, másfél évtizede újra megjelent: GvadÁnyi József, Aprekaszión: névnapi ugratás 1781-böl, kiad. ToRDA István, V. Ecsedy Judit, Zebegény, Borda Antikvárium, 2005.
} 
Nyilvánvalóan újra kell gondolni Fazekas müveinek és a közköltészetnek vagy a folklórnak a lehetséges kapcsolódásait is. Ez a munka több rétegü feladatot jelent. A versek egy részénél fontos kérdés lehet a közköltészeti elöképek tisztázása, illetve mivel bizonyos szövegek névtelenül kezdtek el hagyományozódni - annak a közköltészeti hálózatnak a megragadása, amely Fazekas költészetének az egyik közege lehetett. Olykor tehát a felhasználás, a hagyományba való beleilleszkedés lehet releváns kérdés, máskor pedig az az innováció, amellyel a költő elindít egy hagyományozódást. Mindez nem nélkülözheti a szövegek vizsgálatán túl a dallamok elemzését sem, hiszen bizonyos szövegek eleve énekversként kerültek használatba, illetve Fazekas maga is írt dallamra verseket, mint ezt a református énekeskönyv számára alkotott zsoltárparafrázisa mutatja. ${ }^{25}$ Mindezek a megfontolások pedig más fénybe állíthatják Fazekas lírájának a megítélését is.

A folklorisztikai megközelítés igen lényeges a Lúdas Matyi szempontjából is. Hiszen itt is megmutatkozik egy folklórszüzsé felhasználása egyfelől, a folklorizálódás másfelöl. Ez utóbbit a müről készült variatív másolatok és a ponyvaváltozatok léte mutatja. A Lúdas Matyi alaptörténetének az eredete kapcsán pedig igencsak régi a legutóbbi folklorisztikai elemzés, s ez is igencsak bizonytalan következtetéseket fogalmaz meg, nem manifeszt módon láthatóvá tett forrásbázis alapján. A kritikai kiadás megjelenése óta felhalmozódott szakirodalom és az újabb módszertani háttér alapján egy mai tudásunknak megfelelő interpretáció másként értékelheti azt a nagyszámú adatközlést és párhuzamot, amely a 19. és a 20. században a Lúdas Matyi-történet kapcsán felmerült.

Fazekasnak szerkesztőként köze volt a korszak egyik nagyhatású nyomtatott kiadványtípusához, a kalendáriumhoz is, $s$ ez a tény új távlatot és még elevenebb relevanciát kölcsönöz a popularitás vizsgálatának. Hiszen ez a médium a 19. század első felében tárhelye volt bizonyos folklórműfajoknak is (mint amilyen például a találósok), s a kalendáriumokban közölt névtelen szövegeknek a Fazekas-életműhöz való hozzákötése (vagy éppen az onnan való kizárásuk) nem teljes egyértelműséggel elvégezhető filológiai feladat. Mindazonáltal ez a névtelenségben maradásnak és az ilyen módon történő hagyományozódásnak egy újabb körét jelenti a Fazekas-művek kapcsán, s ezt aligha helyes egy rigorózus irodalomtörténészi logikával megközelíteni, azaz csak azt a kérdést feltenni, vajon bizonyos szövegek teljesen a költő alkotásai-e vagy „csak” kétes hitelüek. Itt fontos lenne a folklorisztika megközelítési módjától tanulni: s ha valami kimutatható, megragadható változatokban létezik, akkor ennek hálózatába beilleszteni a Fazekashoz valamilyen módon kapcsolódó szövegeket, $s$ a névtelen hagyományozódás sajátosságait is hozzákapcsolni - afféle „szürke zóna”-ként - az életmünek mint autonóm, szerzői név köré rendezhetö teljesítménynek a tanulságaihoz.

Éppen ebben a logikai szerkezetben lehet érdekes Fazekas viszonya a természetleírás különböző müfajú változataihoz. Hiszen ezek eleve többféle rétegben ragadhatók meg

\footnotetext{
${ }^{25}$ Erre már a régi kritikai kiadás is felhívta a figyelmet. Lásd a Dícséret című vershez füződő jegyzeteket: FMÖM I. 254-255.
} 
az életműben. A líra korabeli lehetőségei felől kiindulva ebből az érdeklődésből a fizikoteológiához vezetnek az utak, s ennek megragadható és elemezhető jelentősége van Fazekas irodalmi munkásságában - a recens tudományosság körvonalazódó igényei szerint viszont a költő ilyen jellegű érdeklődésében a botanikához és a csillagászathoz kötődő „tudós” beszédmód is megjelent. Ez utóbbiak azok az irányai a Fazekas-életműnek, amelyektől a költővel foglalkozó irodalomtörténészek mindig villámgyorsan el szoktak határolódni, s mivel nem értenek hozzá, elöszeretettel minősítik érdektelennek is az ezekkel való számvetést. Pedig nem szabad elfelejteni, hogy Fazekas legfőbb ambíciója a botanikusként való megmutatkozás volt, $\mathrm{s}$ az is kimutatható, hogy büszkesége arra is kiterjedt, hogy a tőle szerkesztett kalendáriumban az időjóslás helyét „tudós” ismeretek vették át. ${ }^{26}$

A jelenlegi összeállítás ezeknek a szempontoknak és munkahipotézisként megfogalmazott ötleteknek a sokoldalú, módszeres végiggondolására vállalkozott - köszönhetően a kutatásba bekapcsolódott szakemberek hozzáértő munkájának. Egyetlen esetben azonban le kellett mondanunk eredeti tervünkröl: azt szerettük volna, ha születik tanulmány a Füvészkönyv tudománytörténeti jelentőségéről és jelenlegi relevanciájáról is, ám a feladatra kezdetben vállalkozó botanikus kolléga végül nem készítette el a vállalt elemzést, így az erről szóló tanulmány kimaradt a tematikus folyóiratszámból, csak a fájó hiányát tarthatjuk számon. Ám a megcélzott interdiszciplinaritás mégiscsak megvalósult, s ez mindenképpen új színt jelent a Fazekas Mihályra vonatkozó szakirodalomban.

Az összeállítás szerkezete is ezt tükrözi.

Az első fejezetben a több írás számára vitaindítóként rendelkezésre állt szövegeket közöltük: mindkét tanulmány újraközlés, itteni jelenlétüket azonban indokolja, hogy a többi szerző számára reflexióra késztető kiindulópontként szolgáltak. Debreczeni Attila az egész Fazekas-életmű értelmezésének lehetséges kereteit vázolja fel, s idekerült saját, jó másfél évtizede írott, a Lúdas Matyit tárgyazó tanulmányomnak az újraírt változata. Ezért is lett a fejezet címe Perújrafelvétel.

Utána a Versek című rész következik, amelyben a Fazekas verses életművét tárgyaló tanulmányok kaptak helyet. Fazekas költészetének különböző aspektusairól három tanulmány is szól. Vaderna Gábor egy lehetséges ciklusalkotás rekonstrukcióját végezte el a meglehetősen hézagosan fönnmaradt filológiai adatok alapján, s ennek révén figyelemreméltó történeti-poétikai következtetésekre jutott Fazekas lírájának fejlődéstörténeti helyéről. Hovánszki Mária tanulmánya egy Fazekas-vers kapcsán a dallam jelentésének értelemalakító szerepére hozott tanulságos példát: ez a részben közösségi használatra szánt, meglévő dallamokra énekverseket is alkotó Fazekas esetében igen fontos megközelítés, s olyan kontextust jelent (irodalomtörténet és zenetörténet határterületét), amely termékeny távlatokat nyithat meg a 19. századi magyar irodalom

\footnotetext{
${ }^{26}$ Lásd a következő versét: A Debreceni első Kalendáriumba, mellyböl az idöjövendölés kimaradt (FMÖM I. 98-99.)
} 
számos más alkotója kapcsán is. Csörsz Rumen István néhány Fazekas-vers alapján a közköltészeti háttér bevonásával volt képes értelmezni olyan szövegeket (például a Hortobágyi dalt), amelyeknél a korábbi szakirodalom is beleütközött az alapproblémába, hogy itt vajon Fazekas fölhasznált-e egy korábban is ismeretes populáris költészeti sémát vagy toposzt, vagy éppen ő volt ennek a folklorizálódott szöveghagyománynak a kezdeményezője. Gulyás Judit alapos folklorisztikai tanulmánya pedig a Lúdas Matyira koncentrálva fogalmazta újra a verses elbeszélés eredetének és populáris státuszának az alapviszonyát, a jelenleg rendelkezésre álló néprajzi szakirodalom minden eddiginél teljesebb ismeretében.

A Kalendárium címủ egység három tanulmányt foglal magába, mindegyik a kalendárium-szerkesztéssel foglalkozó Fazekas portréjához tesz hozzá új vonásokat. Mikos Éva tanulmánya folklorisztikai szempontból közelítette meg a kalendáriumok világát, s nagy anyagismerettel kontextualizálta ennek a populáris kiadványtípusnak azt a debreceni változatát, amelyhez Fazekasnak mint szerkesztőnek volt köze. A szintén néprajzos Vargha Katalin, aki a találósok szakértője, Fazekasnak az itt publikált verses rejtvényeit értelmezte a müfaj általános jegyei és konkrét magyarországi párhuzamai ismeretében. Jelentős újdonság, hogy ebben a tematikus folyóiratszámban végre a Fazekas szerkesztette kalendáriumok csillagászati szövegeiről Zsoldos Endre személyében csillagász-szakember értekezett - egy olyan területről rajzolván föl átfogó képet, amely mindezidáig rendre kimaradt a Fazekas-szakirodalom áttekintéséből.

Az utolsó egység (Kontextus) egyetlen terjedelmes tanulmányt tartalmaz. A fizikoteologizmus magyarországi történetét áttekintő dolgozat, Imre Mihály munkája Fazekas természettudományi érdeklődésének egyik releváns kapcsolatát vázolta föl, s a természet működéséből az isteni teremtésre következtető, teológiai hátterű gondolkodás változatainak fölmutatásával egy programadónak is tekinthető kutatási irányt mutatott be. Jól példázva ezzel azt is, hogy egy olyan törekvés, amely Fazekas Mihály szellemi környezetét igyekszik feltérképezni, a 18. század egészének és a 19. század elejének eszmetörténeti vagy irodalomtörténeti folyamataihoz is nagyban hozzá tud járulni.

Vállalkozásunk, amely konferencia kívánt volna lenni, de kényszerüen (ám igen szerencsés, $s$ talán maradandóbb módon) egy tematikus folyóiratszám megjelenéséhez vezetett, már akkor is elérte a célját, ha nem új válaszokat fogalmaz meg, hanem segít pontosabban feltenni a kérdéseinket. Mert hiszen minden ezen a múlik. S ha idáig eljutunk, valóban lehet arra mód, hogy a 18. század végének, a 19. század elejének egyik legizgalmasabb, magányos írófigurájáról másféle irodalomtörténeti képet rajzoljunk fel.

Közös munkával.

S akár nem is csak egyet.

SZILÁGYi MÁRTON 